\title{
IMPROVING STUDENTS' ABILITY TO WRITE ENGLISH DISCOURSE BY MASTERING ITS GLOSSARY IN GRADE XI.MIPA 1 SMAN 1 CIGUGUR
}

\author{
Mohamad Muhtar \\ SMA Negeri 1 Cigugur Kabupaten Kuningan \\ much2970@gmail.com
}

\begin{abstract}
The study aims to determine the extent to which students' ability to write English discourse is increased through mastery of the glossary. Glossary mastery is mastery of vocabularies or terms used in the material to be studied. This is one way for the author to make it easier for students to write an English discourse. This is carried out in hybrid learning during the Covid-19 pandemic. This study uses a classroom action research method with a quantitative approach to 32 students of Class XI.MIPA1 SMAN 1 Cigugur which is carried out in 2 cycles in the odd semester of the 2021-2022 academic year. The results showed that 89\% of students were able to write English discourse well. In addition, there was an increase in their writing ability by $27 \%$ from their previous ability.
\end{abstract}

Keyword: Students' writing ability, English discourse, glossary mastery.

\section{INTRODUCTION}

Grade XI senior high school students already have the ability to write English discourse well. This is in accordance with the decree of the Chairman of the Indonesian Book and Research and Development Agency (018/H/KR/2020) concerning Core Competencies and Basic Competencies of Lessons in the 2013 Curriculum in Early Childhood Education, Basic Education, in the form of Senior High Schools for Special Conditions. which states that grade XI students should master the writing of announcement, letters, exposition analysis, and explanations discourse. However, in reality, students in grade XI.MIPA1 of SMAN 1 Cigugur only have the ability to write English discourse reaching a grade average of 68 and the number of students who reach the KKM (minimum ability criteria) is only $62 \%$. While the KKM they must achieve is 73 . Thus, efforts must be made to improve their abilities. The author of this study has tried to use the learning method through mastery of the glossary. So the problem formulation of this research is: Can mastery of the glossary improve the ability of students to write
English discourse in garde XI.MIPA1 SMAN 1 Cigugur?

Mastery of the glossary in learning to write English discourse is very important. The glossary itself is an alphabetical list of difficult, technical, or foreign words in a text along with explanations of their meanings (Cambridge Dictionary, 2021). Furthermore, what is meant by mastery is complete control of something (Cambridge Dictionary, 2021). From these two understandings, it can be concluded that what is meant by mastery of the glossary is the ability of a person to control certain vocabulary or terms used on a subject. So it is not an exaggeration if the mastery of the glossary can improve students' ability to write a discourse. They have a lot of knowledge of vocabulary or terms that are in accordance with the subject matter so it is easy to make a discourse. According to Endang Fauziati in Endah Tri Wahyuningsih (2016), it is stated that vocabulary or vocabulary is the center of language and is important for language learning. Without sufficient vocabulary, a person cannot communicate effectively or express all his ideas both orally and in writing. However, what must be considered at the time of implementing the 
learning, teachers must be able to overcome learning difficulties which are carried out in a hybrid learning, both offline and online, as one of the efforts to prevent COVID-19.

\section{METHODS}

The research uses Classroom Action Research (CAR) with Kemmis and Mc Taggart models. This model is a development of Kurt Lewin's model. According to Kemmis and Mc Taggart (in Rafi'uddin, 1996) action research can be viewed as a spiral cycle of planning, implementing action, observing, and reflecting. The actions taken by the author were carried out in 2 cycles.

Data collection techniques used are observation, questionnaires, and tests. The observation was carried out by the observer on the learning activities carried out by the teacher and students in the classroom using a closed observation sheet instrument. Furthermore, the distribution of questionnaires is carried out after carrying out the learning, which is expected to collect data on student responses to the implementation of learning. Furthermore, research data were collected from the test results. The test in question consists of a written test and performance. The written test is in the form of multiple choice and essay. While the performance test is in the form of preparing discourse according to a predetermined theme. Both of these tests are expected to determine student learning outcomes after participating in learning.

After obtaining the expected data, then data analysis is carried out. Data analysis techniques used are quantitative and qualitative analysis techniques. Qualitative data obtained from observations and questionnaires. While quantitative data were obtained from test results, both in the form of written tests and performance tests. Processing of qualitative data is converted in the form of sentences which are the conclusions of the research results. Meanwhile, quantitative data processing uses simple calculations by finding the average value and the percentage of learning outcomes and performance tests.

The indicators for the success of the research refer to 1) written test completeness and student performance classically at least $85 \%$ of students get a score of 73,2 ) observation results must show a good category, and 3 ) the response shown by students to learning is a positive attitude.

\section{RESULTS}

In the first cycle, it has been shown that the results of observing student and teacher activities in learning are in line with expectations. The results of observation of student activities have shown $70 \%$ which is included in the GOOD category. While the results of observations of teacher activities have reached $88 \%$ or are included in the VERY GOOD category. Furthermore, the results of student responses to learning reached $72 \%$ which is included the POSITIVE category.

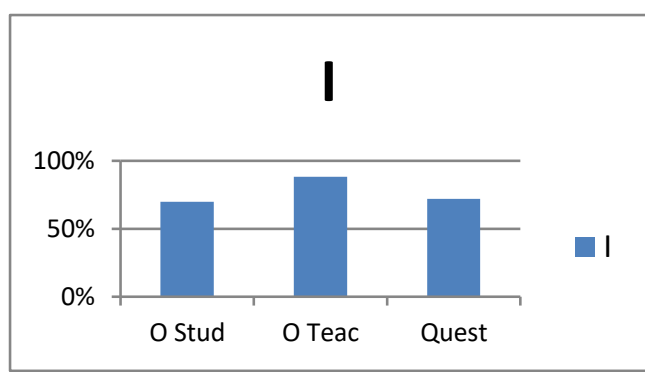

Graph 1. Result of Observation and Questionnaire of Cycle I

In the first cycle, the author did not get the maximum test results. The average of grade that has been achieved is only 74 and has met the KKM, but the number of students who have met the KKM classically only reaches $78 \%$ and has not met the expected success indicators.

Table 1

Result of The Test in Cycle 1

\begin{tabular}{|c|l|c|c|c|}
\hline $\mathbf{N r}$ & Variables & Tes & Perform & Average \\
\hline 1 & Sum & 2365 & 2353 & 2359 \\
\hline 2 & Average & 73,91 & 73,53 & 73,72 \\
\hline 3 & Procent & $74 \%$ & $74 \%$ & $74 \%$ \\
\hline
\end{tabular}




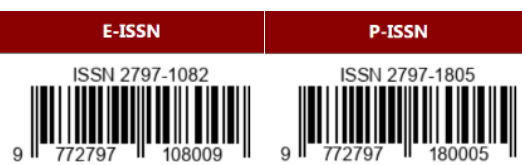

From the results of the first cycle mentioned above, there are several things that must be improved in the learning. These improvements are based on the results of analysis and reflection that have been carried out in cycle I. Weaknesses that must be corrected, especially in the delivery of learning to students simultaneously, both online and offline. Therefore, the author tries to innovate hybrid learning as well as possible so that it is easy to understand for students who take part in learning, both online and offline.

After correcting the deficiencies in the first cycle, the results of the study showed a significant increase. The results of observing student activities in learning reached $90 \%$ and were included in the VERY GOOD category. Likewise, the results of observing teacher activities during learning become $100 \%$ or in the VERY GOOD category. In addition, the responses given by students to the learning reached $91 \%$ or categorized as VERY POSITIVE.

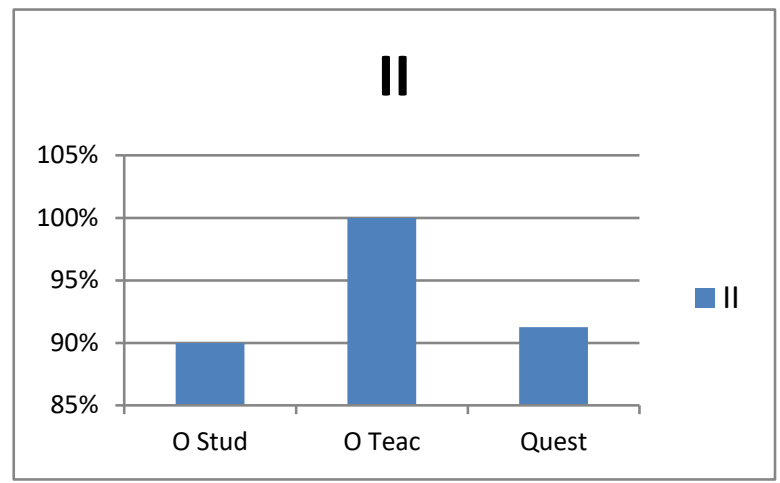

Graph 2. Result of Observation and Questionnaire of Cycle II

Furthermore, in the second cycle there was a significant increase in test results. The garde average of the test results in this cycle is 85 and classically the number of students who have met the KKM reaches $94 \%$. Thus the results have reached the predetermined success indicators.

Table 2

Result of The Test in Cycle II

\begin{tabular}{|c|l|c|c|c|}
\hline $\mathbf{N r}$ & Variables & Tes & Perform & Average \\
\hline 1 & Sum & 2730 & 2735 & 2732,5 \\
\hline 2 & Average & 85,31 & 85,47 & 85,39 \\
\hline 3 & Procent & $85 \%$ & $85 \%$ & $85 \%$ \\
\hline
\end{tabular}

From the results of the research above, it shows that mastery of the glossary can improve students' ability to write discourse. In the first cycle, the mastery of the glossary still did not show maximum results. This is due to the obstacles in students' understanding of the learning material. Basically online learning has limited students to interact with teachers in learning. Next, the teacher fixes it by making additional media such as slides, videos, and audio that are sent via WhatsApp group as communication media in the learning. The results are very helpful for students to understand the learning delivered by the teacher. So do not be surprised if their writing skills are increasing. This can be seen in the increase in the following table.

Table 3

Increased research results from cycle I to cycle II

\begin{tabular}{|c|c|c|c|c|}
\hline Cycles & O Stud & O Teac & Quest & Test \\
\hline I & $70 \%$ & $88 \%$ & $72 \%$ & $78 \%$ \\
\hline II & $90 \%$ & $100 \%$ & $91 \%$ & $94 \%$ \\
\hline
\end{tabular}

\section{CONCLUSION}

The results of this study can be concluded that there is an increase in students' ability to write English discourse by mastering the glossary in class XI.MIPA1 SMAN 1 Cigugur. The magnitude of the increase in writing skills is seen from their learning outcomes in discourse writing. Previously they only got a class average of 68 and 
increased to 85.39 after conducting classroom action research in 2 cycles.

\section{REFERENCES}

Buckelew, Mary. 2019. Action Research for English Language Arts Teachers: Invitation to Inquiry. Routledge; 1st edition (March 22, 2019).

Cambridge University. 2021. Cambridge Dictionary. London: Cambridge University Press.

Endah Tri Wahyuningsih. 2016. "Upaya Meningkatkan Kemampuan Mengenal Kosa Kata Bahasa Inggris melalui Penggunaan Media Papan Flanel pada Anak Kelompok B2 di TK ABA Ambarbinangun Kasihan Bantul". Skripsi. Yogyakarta: Prodi PAUD, Jurusan Pendidikan Anak Usia Dini, Universitas Negeri Yogayakarta.

Kepala Badan Penelitian dan Pengembangan dan Perbukuan. 2020. "Nomor 018/H/KR/2020 tentang Kompetensi Inti dan Kompetensi Dasar Pelajaran Pada Kurikulum 2013 pada Pendidikan anak usia dini, Pendidikan Dasar, berbentuk Sekolah Menengah Atas untuk Kondisi Khusus". Surat Keputusan. Jakarta: Badan Penelitian dan Pengembangan dan Perbukuan.

Mahmudah, Dzur Rif'ah. 2014. "The Correlation between Students' Writing Ability and Their Vocabulary Mastery". Paper. Exposure: Jurnal Pendidikan Bahasa Dan Sastra Inggris, Vol. 3, Nomor 2 (2014).

McCabe, Anne Coen. 1998. English Writing (Competency in Writing Skill). N \& N Publishing.

Rofi'udin, A. H. 1996. "Rancangan Penelitian Tindakan”. Makalah disampaikan pada Lokakarya Tingkat Lanjut Penelitian Kualitatif Angkatan V tahun 1996/1997. Malang: lembaga Penelitian IKIP Malang.
Suharsimi Arikunto. 2007. Penelitian Tindakan Kelas. Jakarta : Bhumi Aksara. 